\title{
Transcriptional activation and localization of expression of Brassica juncea putative metal transport protein BjMTPI
} Balasubramaniam Muthukumar, Bakhtiyor Yakubov and David E Salt*

\author{
Address: Department of Horticulture and Landscape Architecture, 625 Agricultural Mall Drive, Purdue University, West Lafayette, IN 47907-1392 \\ USA \\ Email: Balasubramaniam Muthukumar - muthukum@purdue.edu; Bakhtiyor Yakubov - byakubov@purdue.edu; \\ David E Salt* - dsalt@purdue.edu \\ * Corresponding author
}

Published: 18 June 2007

BMC Plant Biology 2007, 7:32 doi:10.1 |86/147|-2229-7-32
Received: 5 December 2006

Accepted: 18 June 2007

This article is available from: http://www.biomedcentral.com/ I47/-2229/7/32

(c) 2007 Muthukumar et al; licensee BioMed Central Ltd.

This is an Open Access article distributed under the terms of the Creative Commons Attribution License (http://creativecommons.org/licenses/by/2.0), which permits unrestricted use, distribution, and reproduction in any medium, provided the original work is properly cited.

\begin{abstract}
Background: Metal hyperaccumulators, including various Thlaspi species, constitutively express the putative metal transporter MTPI to high levels in shoots. Here we present data on the transcriptional regulation and localization of expression of the homologous gene BjMTPI in Brassica juncea. Though $B$. juncea lacks the ability to hyperaccumulate metals, its relatively high biomass, rapid growth and relatedness to true metal hyperaccumulating plants makes it a promising starting point for the development of plants for phytoremediation. Our goal in this study is to determine the transcriptional regulation of MTPI in order to start to better understanding the physiological role of MTPI in B. juncea.
\end{abstract}

Results: Steady-state mRNA levels of BjMTPI were found to be enhanced 8.8, 5.9, and I.6-fold in five-day-old $B$. juncea seedlings after exposure to $\mathrm{Ni}^{2+}, \mathrm{Cd}^{2+}$ or $\mathrm{Zn}^{2+}$, respectively. This was also reflected in enhanced GUS activity in $B$. juncea seedlings transformed with BjMTPI promoter::GUSPlus after exposure to these metals over a similar range of toxicities from mild to severe. However, no increase in GUS activity was observed after exposure of seedlings to cold or heat stress, $\mathrm{NaCl}$ or hydrogen peroxide. GUS expression in $\mathrm{Ni}^{2+}$ treated seedlings was localized in roots, particularly in the root-shoot transition zone. In four- week- old transgenic plants BjMTPI promoter activity also primarily increased in roots in response to $\mathrm{Ni}^{2+}$ or $\mathrm{Cd}^{2+}$ in plants transformed with either GUS or mRFPI as reporter genes, and expression was localized to the secondary xylem parenchyma. In leaves, BjMTPI promoter activity in response to $\mathrm{Ni}^{2+}$ or $\mathrm{Cd}^{2+}$ spiked after $24 \mathrm{~h}$ then decreased. In shoots GUS expression was prominently present in the vasculature of leaves, and floral parts.

Conclusion: Our studies establish that a 983 bp DNA fragment upstream of the BjMTPI translational start site is sufficient for the specific activation by $\mathrm{Ni}^{2+}$ and $\mathrm{Cd}^{2+}$ of $B j M T P I$ expression primarily in roots. Activation of expression by both metals in roots is primarily localized to the xylem parenchyma cells. This study is the first to identify specific $\mathrm{Ni}^{2+}$ and $\mathrm{Cd}^{2+}$ transcriptional regulation and tissue localization of BjMTPI. 


\section{Background}

Plant Cation Diffusion Facilitator (CDF) family members have been suggested to be involved in metal ion transport, and implicated in metal resistance in plants [1]. However, the physiological role of these transporters is not well understood. AtMTP1 (ZAT) from Arabidopsis thaliana was the first member of the CDF family to be characterized in plants [2]. When ectopically over expressed in A. thaliana AtMTP1 confers enhanced resistance to $\mathrm{Zn}^{2+}$, and increased $\mathrm{Zn}^{2+}$ accumulation in roots [2]. Enhanced $\mathrm{Zn}^{2+}$ resistance and accumulation was attributed to increased vacuolar sequestration of $\mathrm{Zn}^{2+}$. More recent evidence has established that AtMTP1 is predominantly localized at the tonoplast membrane in both root and shoot tissue in $A$. thaliana $[3,4]$. Consistent with a role in $\mathrm{Zn}^{2+}$ transport into the vacuole, reduction in expression of AtMTP1 leads to increased sensitivity to $\mathrm{Zn}^{2+}$, but not $\mathrm{Co}^{2+}, \mathrm{Cd}^{2+}, \mathrm{Ni}^{2+}$ or $\mathrm{Mn}^{2+}[3,4]$. Reduced expression of AtMTP1 also leads to decreased accumulation of $\mathrm{Zn}^{2+}$ in shoots [4]. Reconstruction of AtMTP1 in proteoliposomes, and expression of the AtMTP1 cDNA in Xenopus oocytes has provided direct evidence that AtMTP1 is competent to transport $\mathrm{Zn}^{2+}$ but not $\mathrm{Cd}^{2+}$ or $\mathrm{Co}^{2+}[4,5]$. To date all studies have found that AtMTP1 expression is not modulated by exposure to elevated $\mathrm{Zn}^{2+}, \mathrm{Cd}^{2+}, \mathrm{Co}^{2+}, \mathrm{Cu}^{2+}, \mathrm{Fe}^{2+}$ or $\mathrm{Mn}^{2+}[2,4]$. Expression of AtMTP1 in A. thaliana occurs throughout the plant, though transcript levels are higher in roots than shoots in young seedlings, and expression is higher in the inflorescences [4]. However, little is known about tissue-specific expression patterns of AtMTP1. Such information is critical if we are to integrate the currently available data into a model describing how MTP1 functions within the physiological context of the whole plant.

Homologues of AtMTP1 have been found in other plant species including the hyperaccumulators Thlaspi goesingense [6], Thlaspi caerulescens [7] and Arabidopsis halleri [8]. It has been suggested that the constitutively higher shoot expression of MTP1 in these hyperaccumulators is involved in metal hyperaccumulation $[6,7]$, and recent genetic evidence supports this hypothesis [8]. However, the role of the MTP1 protein in hyperaccumulation is still unknown. In the $\mathrm{Zn}^{2+}$ hyperaccumulator $A$. halleri AhMTP1 appears to be localized at the tonoplast membrane when transiently expressed as an AhMTP1::GFP fusion in A. thaliana protoplasts [8]. Similar localization has also been observed for an MTP1 homologue from poplar [9]. However, in a similar experiment with TgMTP1 from the $\mathrm{Zn}^{2+} / \mathrm{Ni}^{2+}$ hyperaccumulator T. goesingense the GFP fusion protein was found to localize to the plasma membrane when transiently expressed in A. thaliana protoplasts derived from shoot tissue [10]. Resolution of this interesting difference awaits further comparative studies.
Brassica juncea is an amphidiploid plant, resulting from the hybridization of the crop Brassicas Brassica nigra and Brassica campestris (syn. Rapa; [11]). It contains the conserved genomes of both of its diploid parents [12], and is self compatible, unlike other crop Brassica species. Due to its rapid growth and large biomass $B$. juncea has been considered as a possible plant for use in the phytoextraction process, for the removal of pollutant metals from soils by their accumulation into harvestable above ground biomass [13]. The relatedness of $B$. juncea to numerous hyperaccumulators in the Brassicaceae family, and its ability to be self fertilized makes $B$. juncea a potentially good recipient organisms for the bioengineering of a practical phytoextraction plant using genetic material derived from natural hyperaccumulator species [14]. However, such promise has yet to be realized.

Brassica juncea have been shown to accumulate heavy metals, though $B$. juncea is not a hyperaccumulator [15-17]. However, there are no reports available that attribute a specific role of BjMTP1 in metal accumulation in B. juncea. Here we report that both $\mathrm{Ni}^{2+}$ and $\mathrm{Cd}^{2+}$ induce transcriptional activation of BjMTP1 in whole seedlings, as well as root and shoot tissue of mature plants, where as $\mathrm{Zn}^{2+}$ has very little effect on BjMTP1 expression. We establish that a 983 bp DNA fragment upstream of the BjMTP1 translational start site is sufficient for this regulation, and that expression in roots is specifically localized to the xylem parenchyma cells. This study is the first to identify transcriptional regulation and tissue localization of BjMTP1. However, further work is needed to understand the functional role of BjMTP1 in B. juncea's response to $\mathrm{Ni}^{2+}$ and $\mathrm{Cd}^{2+}$.

\section{Results \\ MTPI sequences from $B$. juncea and its parents}

Using AtMTP1 primers MTP1 homologues were amplified from $B$. juncea and its two parents $B$. nigra and $B$. campestris (GenBank accession numbers EF128447, EF128446 and Ef128445, respectively). All Brassica sequences showed $80 \%$ similarity to AtMTP1, and all were devoid of introns similar to AtMTP1. Brassica nigra and B. campestris MTP1 showed $97 \%$ and $95 \%$ similarity to the B. juncea MTP1 sequence, respectively. A phylogenetic analysis of plant MTP1 sequences revealed that all Brassica MTP1 sequences fall into a monophyletic clade, with MTP1 from $B$. juncea being equally related to MTP1 from both its parents [see Additional file 1]. Isolation of the DNA sequence 5' of BjMTP1 (see below) revealed that the next gene upstream of $B j M T P 1$ is $88 \%$ similar to the $A$. thaliana gene locus At2g46790. At2g46790 is the next upstream gene to AtMTP1 in A. thaliana. Such results show that synteny is conserved within the region of MTP1 between B.juncea and A.thaliana, and provides further strong evidence that 
the MTP sequence identified in B. juncea is the B. juncea homologue of AtMTP1.

\section{Isolation and characterization of BjMTP I promoter}

A two-step genome walking technique was used to isolate DNA 5' of the B. juncea MTP1 translational start site. As a first step a 1,561 bp PCR product was amplified from the DraI genomic DNA library and cloned. To isolate additional upstream sequence further genome walking was performed using the PvuII genomic DNA library giving a new 1,721 bp PCR product. Sequence analysis of this 1,721 bp DNA fragment indicated it contains not only the remaining sequence $5^{\prime}$ of BjMTP1 but also partial sequence of the next gene upstream of BjMTP1 which showed $88 \%$ similarity to the A. thaliana gene locus At2g46790 (unknown protein). The 1,561 bp and 1,721 bp DNA fragments were compared and a contiguous $1,786 \mathrm{bp}$ fragment determined. The complete 5 ' upstream region $(1,786 \mathrm{bp})$, as well as the $1,561 \mathrm{bp}$ fragment, were amplified from the $B$. juncea genomic DNA and the PCR products used for all further analysis. A 983 bp DNA fragment 5' of BjMTP1 translational start site was predicted to contain the majority of the regulatory elements within the complete 1,786 bp upstream region, and was therefore also amplified and used for further experiments.

\section{Transcriptional activation of BjMTP I by various metal ions}

Total RNA was isolated from dark grown seven-day-old $B$. juncea seedlings which had been treated with either $5 \mu \mathrm{M}$ $\mathrm{Cd}^{2+}, 25 \mu \mathrm{M} \mathrm{Ni}^{2+}$ or $75 \mu \mathrm{M} \mathrm{Zn}^{2+}$ for $48 \mathrm{~h}$, treatments that also produced maximal GUS activity in transgenic plants expressing a GUS report gene (see below). These three metals were chosen for this study based on the fact that the hyper accumulators that are known to have constitutively elevated MTP1 expression hyperaccumulator Cd, Ni or Zn. BjMTP1 mRNA were quantified using real time quantitative RT-PCR (qRT-PCR) and normalized to BjACTIN2 as an internal control. Steady-state levels of BjMTP1 mRNA were found to be increased after exposure of seedlings to $\mathrm{Cd}^{2+}$ or $\mathrm{Ni}^{2+}$ when compared to the level of expression in the untreated control plants (Figure 1). $\mathrm{Cd}^{2+}$ and $\mathrm{Ni}^{2+}$ treatment caused a 5.9 and 8.8 fold increase in BjMTP1 transcript levels, respectively, compared to untreated control seedlings. Conversely, $\mathrm{Zn}^{2+}$ treated seedlings showed only a minor 1.6-fold increase in BjMTP1 mRNA.

\section{Analysis of the transcriptional competency of the BjMTP I promoter region}

A 983 bp DNA fragment, originating upstream of the BjMTP1 translational start site, was constructed as a transcriptional fusion with the GUSPlus reporter gene [p(1.0)BjMTP1::GUSPlus]. Five-day-old dark grown seedlings stably transformed with $p(1.0) B j M T P 1:: G U S P l u s$

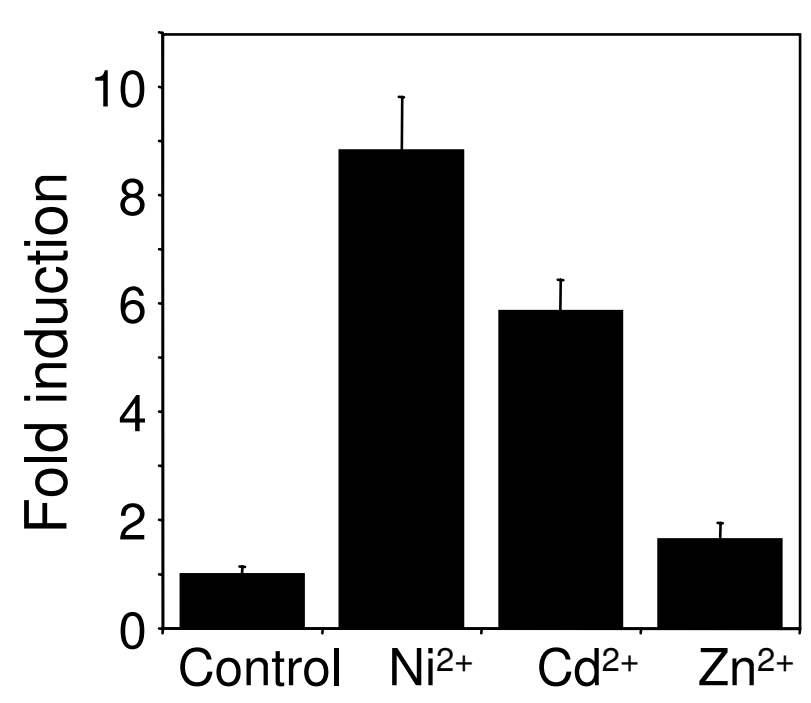

Figure I

Metal regulation of steady-state levels of BjMTPI mRNA. Steady-state levels of BjMTPI mRNA in five-day-old dark grown $B$. juncea seedlings exposed to $\mathrm{Ni}^{2+}(25 \mu \mathrm{M}), \mathrm{Cd}^{2+}(5$ $\mu \mathrm{M})$ or $\mathrm{Zn}^{2+}(75 \mu \mathrm{M})$ for $48 \mathrm{~h}$ measured by qRT-PCR. Data are presented as fold induction $\left(2^{\wedge-} \Delta \Delta C_{T}\right)$, and represent the mean ( \pm standard deviation) of three biological replicates each analyzed four time by qRT-PCR.

were treated with varying concentrations of $\mathrm{Ni}^{2+}, \mathrm{Cd}^{2+}$ and $\mathrm{Zn}^{2+}$ for $48 \mathrm{~h}$ and GUS activity measured (Figure 2). GUS activity was observed to peak at $25 \mu \mathrm{M} \mathrm{Ni}^{2+}, 5 \mu \mathrm{M} \mathrm{Cd}^{2+}$ and $75 \mu \mathrm{M} \mathrm{Zn}{ }^{2+}$, with increases in GUS activity of 3.0, 2.3 and 1.3-fold, respectively (Figure 2A-C). The metal concentrations used in this assay spanned a range from moderately to severally toxic, with the highest concentrations of each metal causing complete loss of turger in the seedlings. To assess the level of toxicity at the end of this $48 \mathrm{~h}$ assay rates of $\mathrm{K}^{+}$leakage from the seedlings were measured. All metal treatments caused an increase in $\mathrm{K}^{+}$leakage peaking at $10 \mu \mathrm{M} \mathrm{Cd}^{2+}$, and $100 \mu \mathrm{M} \mathrm{Ni}^{2+}$ and $\mathrm{Zn}^{2+}$, after which leakage rates dropped and this was associated with a lose of both seedling turger and GUS activity (Figure 2AC). Histochemical GUS staining of both $\mathrm{Cd}^{2+}$ and $\mathrm{Ni}^{2+}$ treated seedlings demonstrated that the GUS protein product of the $p(1.0) B j M T P 1:: G U S P l u s$ construct is localized mainly in the roots, showing strong expression at the root-shoot transition zone (Figure 2D). In the untreated transgenic seedlings, there was no observable GUS staining (Figure 2D).

Plants stably transformed with $p(1.0) B j M T P 1:: G U S P l u s$ were also grown in hydroponic culture for four weeks and transferred to medium of the same composition with the addition of $50 \mu \mathrm{M} \mathrm{Ni}{ }^{2+}$. Root and shoot samples were taken over a $96 \mathrm{~h}$ time course and both $\mathrm{Ni}^{2+}$ accumulation and GUS activity measured. $\mathrm{Ni}^{2+}$ accumulated in both 

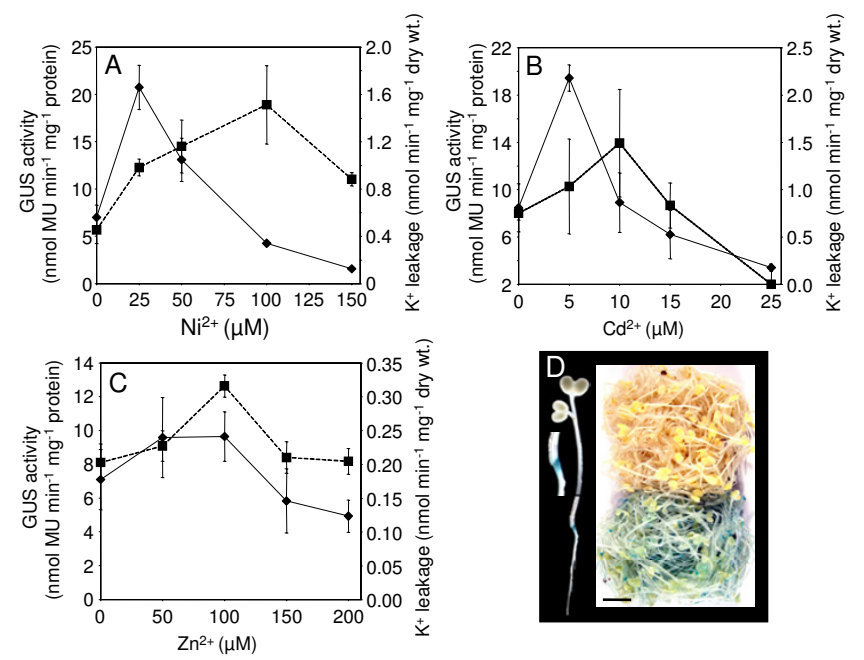

Figure 2

Metal regulated transcriptional activation of BjMTPI by its 983 bp promoter. Five-day-old dark grown seedlings, transformed with $p$ (I.0) BjMTPI::GUSPlus, were exposed to different concentrations of $\mathrm{Ni}^{2+}(\mathbf{A}), \mathrm{Cd}^{2+}(\mathbf{B})$ or $\mathrm{Zn}^{2+}(\mathbf{C})$ and both GUS activity (nmol $\mathrm{MU} / \mathrm{mg}$ protein/min) and $\mathrm{K}^{+}$leakage (nmoles $\mathrm{K}^{+} / \mathrm{min} / \mathrm{mg}$ dry weight) measured. Each data point represents an average $( \pm S D)$ of three independent replicate samples. (D) Histochemical GUS staining of seedlings exposed to $25 \mu \mathrm{M} \mathrm{Ni}^{2+}$ for $48 \mathrm{~h}$ (bottom) and unexposed seedlings (top). Insert shows the GUS localization in an individual seedling. Scale bar $=1 \mathrm{~cm}$.

roots and shoots almost linearly with time, with roots accumulating $\mathrm{Ni}^{2+}$ at approximately 10 times the rate of the shoots (Figure 3A). In root samples, GUS enzyme activity increased linearly as the $\mathrm{Ni}^{2+}$ exposure time increased, with a 3.2 fold increase in GUS activity after 48 $\mathrm{h} \mathrm{Ni}^{2+}$ treatment compared to basal expression $(0 \mathrm{~h})$, or to untransformed control plants (Figure $3 \mathrm{~B}$ ). In shoots, the overall GUS activity was less than in the roots. Interestingly, in shoots GUS activity only transiently increased after $24 \mathrm{~h}$ exposure, compared to untransformed plants, after which GUS activity decreased to levels observed at 0 h exposure (Figure 3B), even though $\mathrm{Ni}^{2+}$ accumulation in shoots continued (Figure 3A). Similar results for both root and shoot expression were also obtained with plants stably transformed with $p(1.0) B j M T P 1:: E Y F P$ (yellow fluorescent protein) (data not shown), and $p(1.0) B j M T P 1:: m R F P 1$ (red fluorescent protein) (Figure 4). A comparison of total tissue $\mathrm{Ni}^{2+}$ accumulation and GUS activity revealed a strong positive correlation between the level of $\mathrm{Ni}^{2+}$ accumulation and GUS activity in roots (Figure $3 \mathrm{C}$ ). In order to test whether the induction process is reversible, after $48 \mathrm{~h} \mathrm{Ni}^{2+}$ treatment plants were transferred to nutrient solution lacking $\mathrm{Ni}^{2+}$. After a further $48 \mathrm{~h}$ recovery GUS activity in roots was observed to return to that observed at $0 \mathrm{~h}$ exposure (Figure 3B). His- tochemical GUS analysis of roots from four-week old plants, after $48 \mathrm{~h} \mathrm{Ni}^{2+}$ treatment, demonstrated clear GUS expression throughout the main root (Figure 3D). After $48 \mathrm{~h} \mathrm{Ni}^{2+}$ treatment GUS expression was not detected in the stem. GUS expression was, however, observed in the vasculature of the leaves (Figure 3E) and in the vascular tissues of the anthers and the stigma (Figure 3F) after 24 hr $\mathrm{Ni}^{2+}$ exposure.

The regulatory competency of the $983 \mathrm{bp}, 1,561 \mathrm{bp}$ and 1,786 bp DNA sequences upstream of the BjMTP1 translations start site were compared to establish if further metal regulatory elements exist upstream of the $983 \mathrm{bp}$ fragment. The transcriptional activity of these DNA frag-
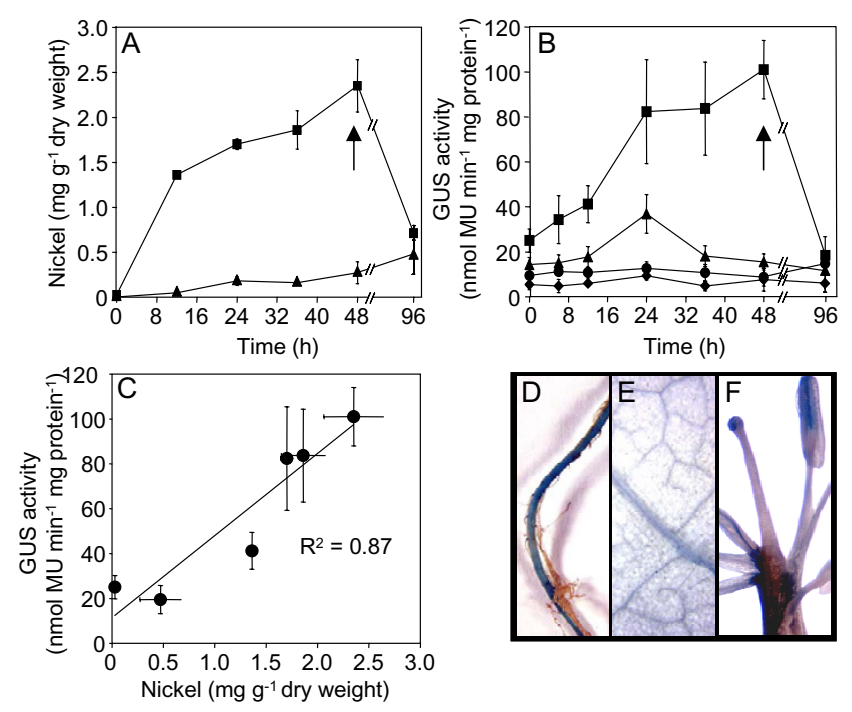

\section{Figure 3}

ICP-MS analysis of Ni, GUS enzyme activity and GUS staining of T2 transgenic plants containing $p$ (I.0) BjMTPI::GUSPlus.(A) ICP-MS analysis of $\mathrm{Ni}$ in T2 transgenic plants containing $P$ (I.0) BjMTPI::GUSPlus after exposure to $50 \mu \mathrm{M} \mathrm{Ni}^{2+}$ in $0.1 \times$ Hoagland's nutrient media. After $48 \mathrm{~h}$ exposure plants were transferred to $0.1 \times$ Hoagland's without $\mathrm{Ni}^{2+}$ (arrow) and $\mathrm{Ni}^{2+}$ accumulation monitored for a further $48 \mathrm{~h}$. Symbols represent roots (squares), and shoots (triangles).

(B) GUS enzyme activity (nmoles of 4-methyl umbelliferone $\mathrm{min}^{-1} \mathrm{mg}^{-1}$ total protein) measured during the same treatment and time frame as in $(\mathbf{A})$. Symbols represent roots (squares), and shoots (triangles) of plants homozygous for the transgene, and roots (circles) and shoots (diamonds) from control plants identified by PCR as null segregants for the transgene. (C) GUS enzyme activity and $\mathrm{Ni}^{2+}$ accumulation, from roots exposed to $50 \mu \mathrm{M} \mathrm{Ni}^{2+}$ for $48 \mathrm{~h}$ (data from $A$ and $B)$. Data represents the average $( \pm S D)$ of three independent replicate samples for both GUS activity and $\mathrm{Ni}$ accumulation. GUS activity visualized by histochemical staining in roots (D), leaves (E) and floral organs (F) from plants exposed to $50 \mu \mathrm{M} \mathrm{Ni}{ }^{2+}$ for $48 \mathrm{~h}$ (roots and floral organs) or $24 \mathrm{~h}$ (leaves). a stigma, $\mathbf{b}$ anther. 
ments was assessed after construction and transformation of $B$. juncea with transcriptional fusions with the monomeric red fluorescent protein ( $m R F P 1)$ as a reporter gene. Hydroponically grown four-week-old $B$. juncea plants transformed with the $m R F P 1$ reporter constructs were exposed to either $5 \mu \mathrm{M} \mathrm{Cd}^{2+}, 50 \mu \mathrm{M} \mathrm{Ni}^{2+}$ or $50 \mu \mathrm{M} \mathrm{Zn}^{2+}$ in aerated $0.1 \times$ Hoaglands solution. Root and shoot samples were collected over a $96 \mathrm{~h}$ time-course and $m R F P 1$ expression quantified using a luminescence spectrometer. As a control for metal related effects on the in vivo stability of mRFP1 pCaMV35S:: mRFP1 transformed plants were also generated and treated in a similar manner. In roots isolated from $\mathrm{Ni}^{2+}$ treated plants, mRFP1 accumulation increased linearly with time of $\mathrm{Ni}^{2+}$ exposure, and the kinetics of mRFP1 accumulation were equivalent regardless of the size of the promoter construct used to drive mRFP1 expression (Figure 4A). All three promoter constructs produced higher mRFP1 accumulation after $48 \mathrm{~h}$ $\mathrm{Ni}^{2+}$ exposure than observed with the CaMV35S promoter. Plants were removed from the $\mathrm{Ni}^{2+}$ containing medium after $48 \mathrm{~h}$ exposure and allowed to recover for a further $48 \mathrm{~h}$. During this recovery period, mRFP1 accumulation decreased linearly with time in a similar manner regardless of the size of the promoter region (Figure 4A). In leaves from $\mathrm{Ni}^{2+}$ exposed plants, all three promoter constructs drove a similar transient increase in mRFP1 accumulation that peaked at $24 \mathrm{~h} \mathrm{Ni}^{2+}$ treatment, after which they declined at a similar rate to the response observed for the promoter GUS construct. mRFP1 expression in plants transformed with $p C a M V 35 S:: m R F P 1$ was constant at all time points and tissues after $\mathrm{Ni}^{2+}$ exposure.

Similar mRFP1 expression was also obtained when plants were exposed to $5 \mu \mathrm{M} \mathrm{Cd}{ }^{2+}$ for $48 \mathrm{~h}$ and allowed to recover from $\mathrm{Cd}^{2+}$ exposure for a further $48 \mathrm{~h}$. mRFP1 accumulated rapidly in roots after $\mathrm{Cd}^{2+}$ exposure to levels equivalent to expression driven by $p$ CaMV35S (Figure 4C). Removal of plants from the $\mathrm{Cd}^{2+}$ containing nutrient solution caused a rapid drop in mRFP1 accumulation, with mRFP1 levels returning to those observed prior to $\mathrm{Cd}^{2+}$ exposure, after $48 \mathrm{~h}$ recovery (Figure $4 \mathrm{C}$ ). Again, all three-promoter sizes gave similar responses. $\mathrm{Cd}^{2+}$ treatment also produced a transient accumulation of mRFP1 in shoots after $24 \mathrm{~h}$ exposure (Figure 4D), as observed during $\mathrm{Ni}^{2+}$ exposure (Figure $4 \mathrm{~B}$ ). Unlike $\mathrm{Ni}^{2+}$ and $\mathrm{Cd}^{2+}$ exposure, $\mathrm{Zn}^{2+}$ treatment produced no significant alteration in MRFP1 accumulation in either root or shoot tissue (Figure. 4E \&4F). Elemental analysis of the nutrient solutions during the $\mathrm{Ni}^{2+}, \mathrm{Cd}^{2+}$ and $\mathrm{Zn}^{2+}$ experiments confirmed that concentrations of $\mathrm{Ni}^{2+}, \mathrm{Cd}^{2+}$ and $\mathrm{Zn}^{2+}$ did not vary significantly in the solution during the course of the experiments (data not shown).
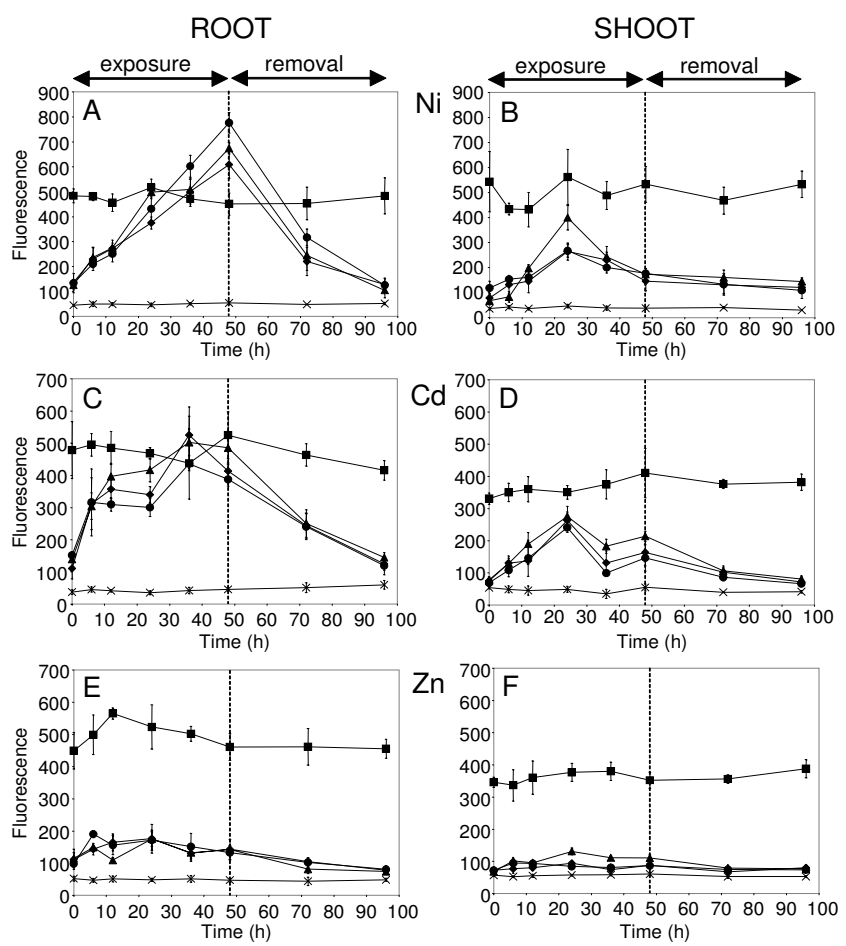

\section{Figure 4}

Expression of mRFP driven by varying sized BjMTPI promoter sequences in response to $\mathrm{Ni}^{2+}, \mathrm{Cd}^{2+}$ and $\mathrm{Zn}^{2+}$ treatment. $48 \mathrm{~h}$ metal treated T2 homozygous and null plants were transferred to $0.1 \times$ Hoagland's medium with out added metals (arrow) and the accumulation was measured again after $48 \mathrm{~h}$. Metal induced mRFPI expression and recovery responses were measured by their relative emission fluorescence at $607 \mathrm{~nm}$. Data represents the average $( \pm$ SD) of three independent replicate samples. Symbols represent null plants (X), CaMV35S promoter: mRFPI (squares), $p(I .0)$ BjMTPI::mRFPI (triangles), p (I.6) BjMTPImRFPI (diamonds) and $p(I .8) B j M T P I:: m R F P I$ (circles).

\section{Response of the $983 \mathrm{bp}$ promoter element to other abiotic stresses}

The 983 bp promoter region, which was found to be sufficient for expression in response to $\mathrm{Cd}^{2+}$ and $\mathrm{Ni}^{2+}$, was also tested for its ability to activate transcription when seedlings were exposed to other abiotic stresses including cold, heat, $\mathrm{NaCl}$ and $\mathrm{H}_{2} \mathrm{O}_{2}$. Five-day-old $B$. juncea seedlings stably transformed with $p$ (1.0) BjMTP1::GUSPlus were exposed to a cold $\left(4^{\circ} \mathrm{C}\right)$ or heat $\left(37^{\circ} \mathrm{C}\right)$ shock, and also $100 \mathrm{mM} \mathrm{NaCl}$, or $\mathrm{H}_{2} \mathrm{O}_{2}(5 \mu \mathrm{M}, 10 \mu \mathrm{M}, 100 \mu \mathrm{M} 500$ $\mu \mathrm{M}$ and $1 \mathrm{mM}$ ) after which GUS activity was assayed. There were no significant increases in GUS activity compared to the untreated seedlings for any of the treatments (Table 1). 
Table I: Different abiotic stress responses of 983 bp promoter element of BjMTPI

\begin{tabular}{cc}
\hline Different stress treatments & $\begin{array}{c}\text { GUS activity (nmoles of 4 -methyl } \\
\text { umbelliferrone } \mathrm{min}^{-1} \mathrm{mg}^{-1} \text { protein) }\end{array}$ \\
\hline Cold shock control & $81.01 \pm 3.89$ \\
Cold shock & $87.7 \pm 4.6 \mathrm{I}$ \\
$\mathrm{Heat}$ shock control & $84.55 \pm 3.13$ \\
Heat shock & $85.21 \pm 6.46$ \\
$\mathrm{NaCl}$ stress control & $99.1 \pm 5.71$ \\
$\mathrm{I} 00 \mathrm{mM} \mathrm{NaCl}$ stress & $98.38 \pm 8.92$ \\
$\mathrm{H}_{2} \mathrm{O}_{2}$ control & $91.46 \pm 3.07$ \\
$50 \mu \mathrm{M} \mathrm{H} \mathrm{H}_{2} \mathrm{O}_{2}$ stress & $96.16 \pm 0.68$ \\
\hline
\end{tabular}

Five-day-old dark grown seedlings stably transformed with P(I.0)BjMTPI::GUSPlus were incubated at $4^{\circ} \mathrm{C}$ for $4 \mathrm{~h}$ (cold shock), $37^{\circ}$ $\mathrm{C}$ for $2 \mathrm{~h}$ (heat shock), $100 \mathrm{mM} \mathrm{NaCl}(24 \mathrm{~h})$ and $50 \mu \mathrm{M} \mathrm{H}_{2} \mathrm{O}_{2}(24 \mathrm{~h})$ and GUS activity measured. Data represents the average $( \pm S D)$ of three independent replicate samples.

\section{Putative regulatory elements in the BjMTPI promoter region}

A search for putative regulatory DNA elements within the 983 bp promoter region of BjMTP1 was performed using the PLACE [18] and PlantCARE databases [19] (Figure 5). DNA regulatory motifs such as the CCAAT boxes, ABRE (Abscisic Acid Response Element), bZIP, G box, and several pathogen responsive elements such as $\mathrm{W}$ box, EIRE, SEBF motif, GCC box, G box coupler and MYB core elements were found. However, no known metal regulatory elements such as MREs which are known to mediate $\mathrm{Zn}^{2+}$ and $\mathrm{Cd}^{2+}$ specific transcriptional activation of metallothionine genes in mammals were found [20-22]. Considering that AtMTP1 appears not to be regulated by $\mathrm{Cd}^{2+}$ [4] and BjMTP1 is (Figure 1, 2, 3, 4), we compared the 983 bp BjMTP1 promoter region with a similar region of the A. thaliana AtMTP1 sequence upstream of the transcriptional start site ( 35715 bp to 36698 bp of $A$. thaliana chromosome 2 clone F19D11). Even though both promoter regions had many known regulatory elements in common, namely bZIP, G box, W box, EIRE box and MYB core element, the BjMTP1 promoter region also has several unique regulatory elements, namely ABRE and pathogen related SEBF motif, GCC box and G box coupler elements (Figure 5). The core sequence of the metal regulatory element [MRE-TGCRCNC [22]] found in mammals (mouse), is present in the full $1786 \mathrm{bp}$ upstream region of BjMTP1 with a single base pair difference (TGCACTG). However, because this motif is not present in the $983 \mathrm{bp}$ promoter region sufficient for $\mathrm{Cd}^{2+}$ and $\mathrm{Ni}^{2+}$ regulation (Figure 2, 3, 4), this MRE is unlikely to play a role in the $\mathrm{Cd}^{2+}$ and $\mathrm{Ni}^{2+}$ transcriptional regulation of BjMTP1.

\section{Localization of BjMTP I expression to root xylem parenchyma}

Our results demonstrate that a $983 \mathrm{bp}$ region upstream of the translational start site of BjMTP1 is sufficient to drive

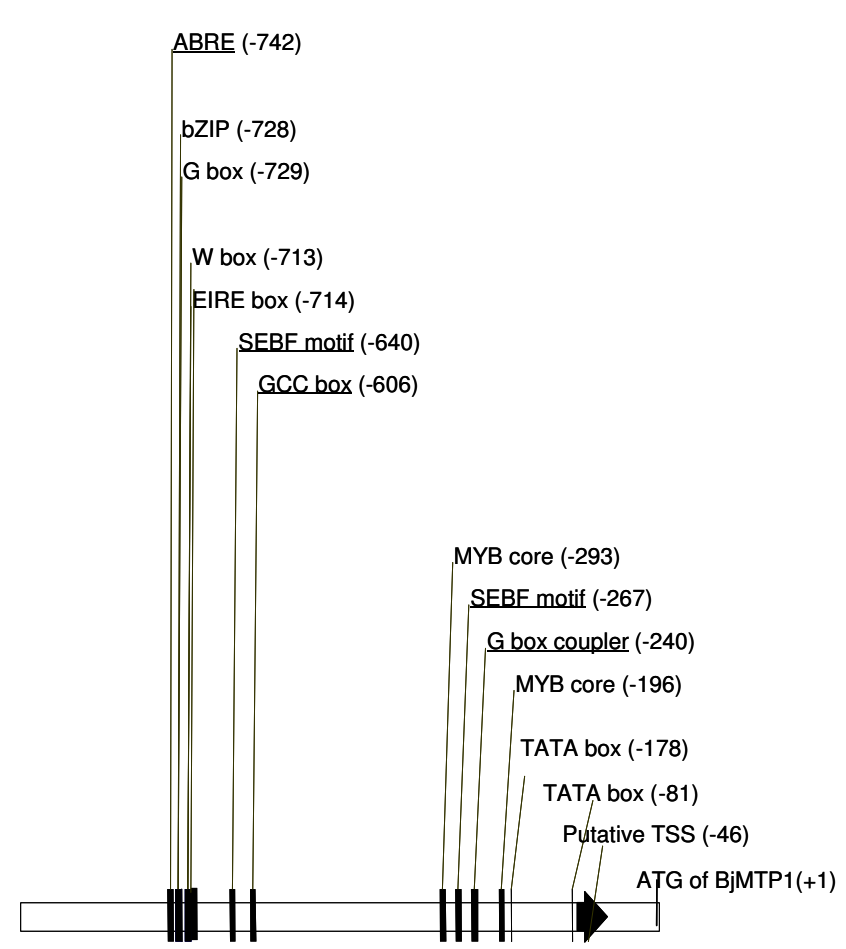

\section{Figure 5}

Regulatory motif analysis of a 983 bp sequence upstream of the BjMTPI translational start site was done region using PLACE and PlantCARE databases. Regulatory motif analysis was also done for similar sequences upstream of the transcriptional start sites (TSS) of AtMTPI and BjMTPI. Unique elements only identified in BjMTPI are underlined..

strong root expression of GUS and mRFP1 in response to $\mathrm{Cd}^{2+}$ or $\mathrm{Ni}^{2+}$ treatment (Figure 2, 3, 4). However, in order to help understand the function of BjMTP1, it is also important to identify which root tissues are expressing BjMTP1 during the response to $\mathrm{Cd}^{2+}$ or $\mathrm{Ni}^{2+}$ exposure. Sections from the main root and intact lateral roots of fourweek-old $B$. juncea plants expressing $m R F P 1$ in response to $\mathrm{Ni}^{2+}$ were analyzed by epifluorescence and light microscope (Figure 6). Sections were taken from the top of the main root as well as $1.5 \mathrm{~cm}$ from the root tip, and the morphology of the roots examined (Figure. 6A \&6B). The main root has clearly undergone secondary growth. The epidermis found in the primary roots has been replaced in 4-week-old roots by periderm produced by the cork cambium. Within the periderm lies the pericycle, and the cambial zone which gives rise to the secondary phloem and secondary xylem. The secondary xylem parenchyma, produced by vascular cambium, was observed surrounding the secondary xylem vessels. The presence of diarch xylem at the center of the root section is a characteristic of the Brassicaceae family (personal communication G. Myer, South Dakota State University). Sections taken $1.5 \mathrm{~cm}$ from the tip of the main root were observed to have simi- 
lar root architecture to sections taken from the top of the root. After exposure to $\mathrm{Ni}^{2+}$ mRFP1 fluorescence was observed to be specifically localized in the secondary xylem parenchyma tissues that surround the secondary xylem (Figure. 6C \&6D). Fluorescence from mRFP1 was also present in the periderm (Figure. 6C) but no significant fluorescence was observed in other root tissues. In the lateral roots, mRFP1 fluorescence was clearly evident in the vascular region (Figure. $6 \mathrm{E}$ and $6 \mathrm{~F}$ ). After $\mathrm{Ni}^{2+}$ exposure no fluorescence was observed in roots from plants identified as null segregants for the reporter construct even after longer ( $6 \mathrm{~s}$ ) exposures, compared to the shorter (100 ms) exposure for $\mathrm{Ni}^{2+}$-treated transgenic plants [see Additional file 2]. $\mathrm{Cd}^{2+}$ treated roots gave an equivalent expression pattern to that of $\mathrm{Ni}^{2+}$ treated plants [see Additional file 2]. In both $\mathrm{Ni}^{2+}$ and $\mathrm{Cd}^{2+}$ treated roots there was no difference in the pattern of mRFP1 accumulation between sections taken from the top of the main root and its tip. Furthermore, mRFP1 expression was localized in the secondary xylem parenchyma tissues when expressed from the $983,1,561$ or 1,786 bp promoter regions. The strong accumulation of mRFP1 observed in the vascular tissue of intact lateral roots (Figure. 6E \&6F) is also consistent with the secondary xylem parenchyma localization observed in the root cross-sections. Cross-sections of roots prepared from $\mathrm{Ni}^{2+}$ exposed plants transformed with the GUSplus reporter gene also revealed strong GUS expression in the secondary xylem parenchyma surrounding the secondary xylem (Figure. 6G), similar to that observed for mRFP1 expression (Figure. 6C \&6D). Secondary xylem parenchyma localization was also observed in plants expressing a EYFP reporter driven by the 983 bp promoter region [see Additional file 2].

\section{Discussion}

Here we establish that mRNA levels of BjMTP1 in B. juncea are transcriptionally regulated in response to $\mathrm{Cd}^{2+}$ and $\mathrm{Ni}^{2+}$, with maximal expression in the root xylem parenchyma cells. We identify a 983 bp DNA fragment, within the total 1,786 bp DNA sequence upstream of the BjMTP1 translational start site, which is sufficient for this transcriptional regulation, which appears specific to stress induced by $\mathrm{Cd}^{2+}$ and $\mathrm{Ni}^{2+}$. BjMTP1 promoter activity in response to $\mathrm{Ni}^{2+}, \mathrm{Cd}^{2+}$ and $\mathrm{Zn}^{2+}$ was assessed at concentrations that span a similar range of toxicities from mild to serve. Over these similar ranges of metal-induced stress only $\mathrm{Ni}^{2+}$ and $\mathrm{Cd}^{2+}$ were observed to elicit a transcriptional response from the BjMTP1 promoter, with $\mathrm{Zn}^{2+}$ induced stress having no significant effect. Other forms of abiotic stress including cold, heat or $\mathrm{NaCl}$ also produced no significant transcriptional response. Transcriptional activation of BjMTP1 promoter by $\mathrm{Cd}^{2+}$ and $\mathrm{Ni}^{2+}$ is also not an indirect response to oxidative stress, since this promoter region is not activated by direct exposure to $\mathrm{H}_{2} \mathrm{O}_{2}$.

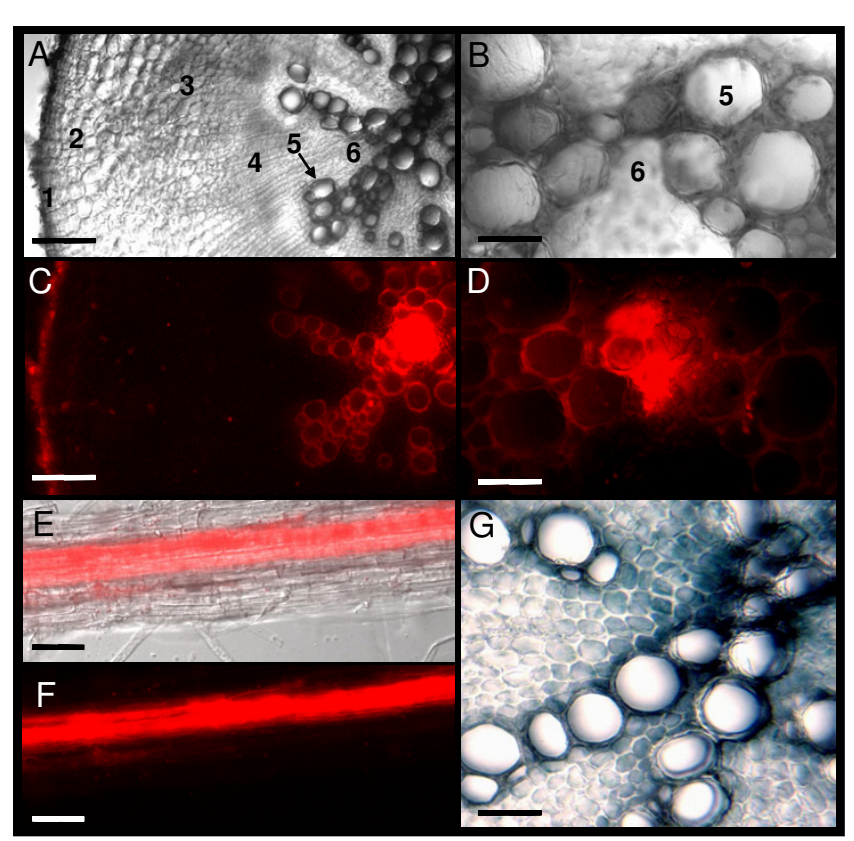

\section{Figure 6}

Microscopic analysis of roots from T2 homozygous transgenic plants ( $p$ BjMTPI::mRFPI and GUSPlus) after exposure to $50 \mu \mathrm{M} \mathrm{Ni}^{2+}$ for $48 \mathrm{~h}$. Images of cross sections taken from the top of the main root under bright field illumination, using diascopic filters at $10 \times(\mathbf{A})$ and $20 \times(\mathbf{B})$ magnification, and fluorescent images of the same sections using a RhodamineTexas red filter at $10 \times($ C) and $20 \times$ (D) magnification.. Root morphology in (A) and (B) labeled as follows. (I) periderm, (2) pericycle, (3) secondary phloem, (4) cambial zone, (5) secondary xylem and (6) secondary xylem parenchyma. Lateral root showing an overlay of a bright field and fluorescent image (E) and fluorescent image alone (F). Image of a root cross section showing GUS activity at $20 \times$ magnification. Scale bar $=40 \mu \mathrm{m}$ for B, D, E, F, G and $120 \mu \mathrm{m}$ for A and C.

Our results are consistent with the observation in A. thaliana that the homologue AtMTP1 is also not regulated by $\mathrm{Zn}^{2+}[2-4,8]$. However, our observation that BjMTP1 expression is transcriptionally regulated by $\mathrm{Cd}^{2+}$ and $\mathrm{Ni}^{2+}$ is not consistent with that observed in $A$. thaliana, where AtMTP1 mRNA levels are unaffected by $\mathrm{Cd}^{2+}[4]$. Our results suggests that rather than being a house-keeping gene involved in $\mathrm{Zn}^{2+}$ homeostasis as has been suggested in A. thaliana, in B. juncea BjMTP1 may be involved in the dynamic regulation of $\mathrm{Zn}$ homeostasis as part of the plant's response to $\mathrm{Cd}^{2+}$ and $\mathrm{Ni}^{2+}$ induced stress. We emphasize that our data does not suggest that the function of BjMTP1 is to transport $\mathrm{Cd}^{2+}$ or $\mathrm{Ni}^{2+}$, for which we have no evidence. However, increased expression of BjMTP1 under $\mathrm{Cd}^{2+}$ or $\mathrm{Ni}^{2+}$ stress may be required to adjust $\mathrm{Zn}$ homeostasis as a response to the stress imposed by exposure to $\mathrm{Cd}^{2+}$ or $\mathrm{Ni}^{2+}$. This is supported by our observation that expression of BjMTP1 promoter is dynamically regu- 
lated in response to these metals, rapidly increasing after exposure to $\mathrm{Cd}^{2+}$ and $\mathrm{Ni}^{2+}$, and rapidly returning back to basal levels after these metals are removed from the growth medium.

Though expression of the BjMTP1 promoter in response to $\mathrm{Cd}^{2+}$ and $\mathrm{Ni}^{2+}$ is highest in roots, expression was also observed in the vascular tissue of leaves, anthers and in the stigma. Expression of BjMTP1 in these tissues suggests that the BjMTP1 protein may also be involved in the plants response to $\mathrm{Cd}^{2+}$ and $\mathrm{Ni}^{2+}$ stress in leaves and inflorescences. Though transcriptional activation of the $983 \mathrm{bp}$ promoter region in roots by $\mathrm{Cd}^{2+}$ or $\mathrm{Ni}^{2+}$ occurs nearly in a linear fashion with time of exposure and accumulation, shoot activation appears transient. After $24 \mathrm{~h}$ of metal exposure transcription of BjMTP1 reaches a maximum and then declines to baseline expression after $48 \mathrm{~h}$. Such transient expression is intriguing considering that over the same time frame $\mathrm{Ni}^{2+}$ accumulates linearly in shoots. The different expression patterns of BjMTP1 promoter in roots and shoots imply that this protein plays different roles in the plant's coordinated response to $\mathrm{Cd}^{2+}$ and $\mathrm{Ni}^{2+}$ exposure, though what these roles are remain unclear at this time.

In five-day-old seedlings of $B$. juncea expression of BjMTP1 promoter in response to $\mathrm{Cd}^{2+}$ and $\mathrm{Ni}^{2+}$ occurs throughout the seedlings, though is especially localized to the root and shoot-root transition zone. Though the reasons for stronger expression BjMTP1 promoter in the shoot-root transition zone are not known, this type of expression pattern has been observed previously for several proteins, including naphthylphthalmic acid (NPA) associated amino peptidases, glutathione $S$-transferase ATGSTF2, the auxin transporter PIN2, and PGP4 an ABC type transporter [23-26].

When compared to $A$. thaliana, the unique elements present in the BjMTP1 promoter region, including ABRE, SEBF motif, GCC box and G box coupler elements all have known functions in ABA signaling [27] or pathogen related stress [28-30]. However, none of these promoter elements have been established to play a role in signaling $\mathrm{Cd}^{2+}$ or $\mathrm{Ni}^{2+}$ stress. The elements responsible for regulation of BjMTP1 expression in response to $\mathrm{Cd}^{2+}$ and $\mathrm{Ni}^{2+}$ remain to be identified. This study is the first to identify transcriptional regulation and tissue localization of BjMTP1. However, further work is needed to understand the functional role of BjMTP1 in B. juncea's response to $\mathrm{Ni}^{2+}$ and $\mathrm{Cd}^{2+}$.

\section{Conclusion}

Here we conclude that a 983 bp DNA fragment upstream of the BjMTP1 translational start site is sufficient for the specific activation by $\mathrm{Ni}^{2+}$ and $\mathrm{Cd}^{2+}$ of BjMTP1 expression primarily in roots. Activation of expression by both metals in roots is primarily localized to the xylem parenchyma cells. This study is the first to identify specific $\mathrm{Ni}^{2+}$ and $\mathrm{Cd}^{2+}$ transcriptional regulation and tissue localization of BjMTP1 and supports the conclusion that BjMTP1 is involved in the response of $B$. juncea to $\mathrm{Ni}^{2+}$ and $\mathrm{Cd}^{2+}$ exposure.

\section{Methods \\ Plant material}

Indian mustard (Brassica juncea) seeds (accession no. 426308) were obtained from the North central regional plant introduction station (Ames, IA) Brassica juncea seeds (30 seeds) were germinated and grown in $800 \mathrm{~mL}$ of continuously aerated distilled water as described in [16]. Seedlings were maintained in the dark at $21^{\circ} \mathrm{C}$ for 5 days, and the water changed on every third day. Brassica juncea plants were also grown hydroponically in $8 \mathrm{~L}$ of aerated $0.1 \times$ Hoagland's medium [31]., changed weekly, for four weeks with $16 \mathrm{~h}$ light $\left(150 \mu \mathrm{mol} \mathrm{m} \mathrm{m}^{-2} \mathrm{~s}^{-1}\right)$ at $25^{\circ} \mathrm{C}$. All transgenic plants used in the study were homozygous for the transgene.

\section{Cloning of MTP I genomic DNA}

Genomic DNA was isolated from 10-day-old B. juncea, $B$. nigra and $B$. campestris seedlings using a DNeasy plant mini kit (Qiagen, Valencia, CA). Taking advantage of the fact that AtMTP1 contains no introns, we isolated full length BjMTP1 cDNA by PCR using 5'-ATGGAGTCTTCAAGTCCCCA- 3 '(forward primer) and 5'TAGAGCGCTCGATTTGTAT-3' (reverse primer) primers based on the AtMTP1 sequences. After obtaining genomic sequences $5^{\prime}$ of BjMTP1 by genome walking (see below) BjMTP1, BnMTP1 and BcMTP1 genomic DNAs were reamplified using forward primer 5'- ATGGCGTATTCAAGCCCCCAACG- $3^{\prime}$ and reverse primer 5'GCTCTAGAGCGCTCGATTTGTATGG -3' designed based on the sequence of BjMTP1. Conditions used in all the PCR reactions are as follows: initial denaturation $94^{\circ} \mathrm{C}$ followed by 30 cycles of $94^{\circ} \mathrm{C} 30 \mathrm{sec}, 55^{\circ} \mathrm{C} 40 \mathrm{sec}, 72^{\circ}$ $\mathrm{C} 1 \mathrm{~min}$ and $30 \mathrm{sec}$ and final extension at $72^{\circ} \mathrm{C}$ for 10 min. PCR products was cloned into the pGEM T-Easy vector system and sequenced using Big dye terminator $\mathrm{v} 3.0$ method (Applied Biosystems Foster city, CA) with universal M13 primers.

\section{Analysis of BjMTP I mRNA expression in five day old seedlings}

For metal treatment five-day-old dark grown seedlings were transferred to distilled water containing $25 \mu \mathrm{M} \mathrm{Ni}^{2+}$, $75 \mu \mathrm{M} \mathrm{Zn}^{2+}$ or $5 \mu \mathrm{M} \mathrm{Cd}^{2+}$ and incubated for a further $48 \mathrm{~h}$ in the dark with aeration. After metal treatment seedlings were washed in distilled water before proceeding to further analysis. Three independent replicate samples were used for all analyses. Metal concentrations were chosen 
based on the concentrations that produced the maximal increase in GUS activity in transgenic B. juncea containing a BjMTP1 promoter::GUS construct (see below).

Total RNA from metal exposed seedlings was isolated using the RNeasy mini kit (Qiagen, Valencia, CA) using the DNase digestion step to reduce DNA contamination. cDNA was reverse transcribed using $4 \mu \mathrm{g}$ of total RNA and 200 U Superscript III reverse transcriptase (Invitrogen, CA) primed with 100 ng of random hexamers (Invitrogen life technologies, Carbsbad, CA), and the cDNA diluted to $2.6 \mathrm{ng} \mathrm{L}^{-1}$. Real time quantitative PCR was done as previously described [32]. BjACTIN2 was used as a normalization control for the relative quantification of transcript levels. Since the B. juncea ACTIN2 gene sequence was not available A. thaliana ACTIN2 primers (forward primer-5'AAGATCTGGCATCACACTTTC- 3', reverse primer-5'TAGTCAACAGCAACAAAGGAG- 3') were used to amplify a 529 bp homolog from B. juncea. For qRT-PCR primers were designed to generate $~ 100$ bp products using Primer Express v. 2.0 software (Applied Biosystems, Foster City, CA, USA). Primers used for qRT-PCR were as follows: BjACTIN2 forward primer-5'-GAGGATGGCATGTGGAAGAGA- 3', reverse primer- 5' -GTGCTGGATTCTGGTGATGGT- 3', BjMTP1 forward primer- 5'TGCGGCTTCTCAGATCTCAA- 3' and reverse primer-5'TGCGCATGGAGGCATTG- 3'. Quantitative RT- PCR was performed on an ABI Prism 7000 Sequence Detection System (Applied Biosystems Foster City, CA, USA), following the manufacturers recommendations, and optimized primer concentrations were selected based on denaturing curve analysis and the fewest cycles needed to cross the critical threshold $(\mathrm{Ct})$. Four reactions were done per biological sample and three independent replicate samples per treatment were used. SYBR Green PCR Master Mix (Applied Biosystems) was used to detect cDNA amplification. Data was analyzed using the SDS software (Applied Biosystems version 1.0), following the method of Livak and Schmittgen [33]. Ct values were determined based on efficiency of amplification. The mean $\mathrm{Ct}$ values were normalized against the corresponding BjACTIN2 Ct values and calculated as $\left(\mathrm{Ct}_{B j M T P 1^{-}} \mathrm{Ct}{ }_{B j A C T I N 2}\right)$. The relative expression of BjMTP1 was calculated as fold induction from untreated seedlings using the $2^{-\Delta \Delta \mathrm{Ct}}$ method $(\Delta \Delta \mathrm{Ct}=$ $\left(\mathrm{Ct}_{\mathrm{BjMTP1}}-\mathrm{Ct}_{\mathrm{BjACTIN2}}\right)$ metal treated - $\left(\mathrm{Ct}_{\mathrm{BjMTP1}}-\mathrm{Ct}_{\mathrm{BJACTIN2}}\right)$ untreated [33]). The data is presented as fold change in BjMTP1 gene expression (normalized to BjACTIN2) relative to the untreated control seedlings. For untreated control samples $2^{-\Delta \Delta \mathrm{Ct}}$ is one since $\Delta \Delta \mathrm{Ct}$ is zero. The final standard error was estimated by evaluating the $2-\Delta \Delta \mathrm{Ct}$ term using $\Delta \Delta \mathrm{Ct}$ plus standard deviation and $\Delta \Delta \mathrm{Ct}$ minus the standard deviation [33].

\section{BjMTPI promoter::report gene construction}

For the isolation of the $5^{\prime}$ sequence upstream of the BjMTP1 translational start site we used a Universal Genome Walker kit (Clontech, Mountain View, CA) following the manufacturer's protocol. First round of DNA fragment amplification used BjMTP1 gene specific primers, GSP1 5'-GAAGAAAGCACGACAAGTCTGGCAAGTTTA-3' and GSP2 -5'CGTGCTTTCTTCAACGGCTTTGCTGC- $3^{\prime}$ (nested), located (+) 49 to $(+) 78$ bp and (+) 3 to (+) 31 bp relative to the translational start site. For second round amplification primers were 5'-CTGCTAGCTTCTTCCTGCAATCATAT-3' and 5'-ACCTGTAGTAATCAACCTCAGTTACC-3 (nested) located (-) 1302 to (-) 1328 bp and (-)1337 to () 1357 bp relative to translational start site. PCR amplified products were cloned into either pGEM T-Easy vector system (Promega Corporation, Madison, WI) or PCR-XLTOPO vector (Invitrogen Life Technologies, Carbsbad, $\mathrm{CA})$. Cloned constructs were transformed into chemically competent E. coli Top10 F- cells (Invitrogen Life Technologies, Carbsbad, CA). Positive clones were sequenced using Big dye terminator v 3.0 method (Applied Biosystems Foster city, CA) with universal M13 primers. DNA sequences were analyzed by BlastN [34] and known regulatory elements identified using PLACE [18] and PlantCARE [19]. Putative eukaryotic promoter analysis was done using BGDP, a neural network eukaryotic promoter prediction program [35]. BjMTP1 promoter sequence has been submitted to Genbank (\#EF128447).

The GUSPlus gene was PCR amplified from pCambia 1305.1 binary vector using high fidelity Platinum TAQ DNA polymerase (Invitrogen life technologies, Carlsbad, CA) and gene specific primers complementary to the GUSPlus gene. The sense and antisense primers contained engineered EcoRI and BamHI sites, respectively. The GUSPlus primers used were: GUSPlus-BamHI-5'-CGGGATCCCATGGTAGATCTGAGGGTAAATTTCTAGT- 3', GUSPlus EcoRI -5'-CGGAATTCTCACACGTGATGGTGATGGTGATGGCTAGC- 3'. PCR products were cloned into pGEM TEasy vector. The cloned PCR products were chemically transformed into E. coli DH5 $\alpha$, positive clones digested with BamHI and EcoRI and the released cDNAs cloned into the CaMV35S cassette-pUC19 [36] using the same restriction enzyme sites. The insertion of the CDNA product in the correct orientation was confirmed by PCR using promoter specific and 35S PolyA tail specific primers (5'ATAAGAATGCGGCGATATCGATATCGATCTGGATTT-

TAGTA-3'), and further confirmed by sequencing. Using unique EcoRV sites the entire promoter cassettes were cloned into pGreen 0229 binary vector containing the bar gene as a selectable marker. mRFP1 [37] was directly isolated from the pRSET B vector and cloned into CaMV35S cassette using BamHI-EcoRI sites. 
Based on the previously identified sequence information, different sizes of BjMTP1 promoter regions were PCR amplified using high fidelity platinum Taq DNA polymerase with 5' PstI- 3' BamHI promoter specific primers. The primers used were Bj 983 bp 5' PstI 5'-AACTGCAGAGTTTCCATTTTTGTTTTCGTGCTAAATAA-3', Bj1561 bp 5' PstI-5'-AACTGCAGTGCACTGATGAAGTTCCGGATGAAGAGGAA-3', Bj 1786 bp 5' PstI-5'-AACTGCAGACAGACAAAACCAGTTTCTTCAGTCCGGGA-3' and $\mathrm{Bj}$ rev BamHI-5'-CGGGATCCTCTGAAAAGAAAAAAATCAGAGAAAGTTCA-3'. The PCR amplified BjMTP1 promoter regions were cloned into PCR-XL-TOPO vector. Positive clones containing PCR-XL-TOPO: BjMTP1 promoter regions were digested with PstI and BamHI and the released DNA cloned into pGreen 0229 containing specific reporter gene cassettes outlined above, after removing the CaMV35S promoter from the vector by PstIBamHI digestion. All the cloned promoter regions (983 bp, 1,561 bp and 1,786 bp) contained the respective 5' UTR of the BjMTP1 gene and all the constructs contained only the start codon from their respective reporter genes. The ligated constructs were transformed into E. coli DH5 $\alpha$. Positive clones were identified by PCR using a combination of promoter specific and reporter gene specific primers and further confirmed by sequencing. All the pGreen constructs were mixed with pSoup plasmid DNA and transformed into electro competent disarmed Agrobacterium tumefaciens GV3101. Positive clones were selected by colony PCR.

\section{Plant transformation and regeneration}

Transgenic $B$. juncea plants were obtained by tissue culture based on a previously established protocol (personal communication Thomas Leustek, Rutgers University). Briefly, petioles were excised from cotyledons of five-dayold in vitro grown seedlings on agar solidified half strength MS medium [38] and cultured in MS medium with $3 \%$ (w/v) sucrose, $2.5 \mathrm{~g} \mathrm{~L}^{-1}$ Gelrite, $2 \mathrm{mg} \mathrm{L}^{-1}$ 6-benzylaminopurine, and $0.1 \mathrm{mg} \mathrm{L}^{-1}$ naphthalene acetic acid under a 16 hour photoperiod $\left(100 \mu \mathrm{mol} \mathrm{m}^{-2} \mathrm{~s}^{-1}\right)$ at $25^{\circ} \mathrm{C}$ for 2 days. Petioles were transformed with A. tumefaciens GV3101 harboring pGreen 0229 containing BjMTP1 promoter reporter gene constructs.Agrobacterium tumefaciens strain GV3101 carrying the pGreen vectors were grown for $48 \mathrm{~h}$ in $30 \mathrm{~mL}$ liquid YEP medium containing $1 \mathrm{~g} \mathrm{~L}^{-1}$ yeast extract, $5 \mathrm{~g} \mathrm{~L}^{-1}$ beef extract, $5 \mathrm{~g} \mathrm{~L}^{-1}$ bacto-peptone, $5 \mathrm{~g} \mathrm{~L}^{-1}$ sucrose, $0.5 \mathrm{~g} \mathrm{~L}^{-1} \mathrm{MgSO}_{4} .7 \mathrm{H}_{2} \mathrm{O}$ and $100 \mathrm{mg} \mathrm{L}^{-1}$ kanamycin in a $28^{\circ} \mathrm{C}$ shaker at $250 \mathrm{rpm}$ until the culture reached an $\mathrm{OD}_{600}$ of 0.7 . Bacteria were harvested by centrifugation and the bacterial pellet resuspended in $30 \mathrm{~mL}$ MS liquid medium. Petioles were incubated with the A. tumefaciens suspension for $20 \mathrm{~min}$, blotted dry using sterile filter paper and transferred to freshly prepared tobacco (BY2 cell line) feeder layer plates. After $48 \mathrm{~h}$ incubation in the dark, petioles were rinsed in medium containing MS salt,
$3 \%(\mathrm{w} / \mathrm{v})$ sucrose, and $500 \mathrm{mg} \mathrm{L}^{-1}$ carbencillin for $40 \mathrm{~min}$. The petioles were cultured on MS medium containing 2 $\mathrm{mg} \mathrm{L}^{-1} \mathrm{TDZ}$ and $0.1 \mathrm{mg} \mathrm{L}^{-1} \mathrm{IAA}$ with $500 \mathrm{mg} \mathrm{L}^{-1}$ carbenicillin for three to four weeks under $16 \mathrm{~h}$ photoperiod (100 $\mu \mathrm{mol} \mathrm{m} \mathrm{m}^{-2} \mathrm{~s}^{-1}$ ). Roots were induced from regenerated shoots in solid MS medium containing $2 \mathrm{mg} \mathrm{L}^{-1}$ indole-3butyric acid. Plantlets were later transferred to soil for further growth. Putative transformants were selected based on their ability to grow in regeneration medium containing $3 \mathrm{mg} \mathrm{L}^{-1}$ glufosinate ammonium (active ingredient of Basta). Transformants were also analyzed for the presence of the introduced DNA constructs using PCR. T2 and T3 homozygous lines were selected by spraying BASTA ( $8 \mathrm{mg}$ $\mathrm{L}^{-1}$ ) on 15-day old plants with fully expanded first leaves (total of 4 applications on every third day), and further confirmed by PCR.

\section{Analysis of BjMTP I promoter activity}

For analysis of metal regulated promoter activity five-dayold dark grown seedlings were treated with various concentrations of $\mathrm{Ni}^{2+}, \mathrm{Cd}^{2+}$ and $\mathrm{Zn}^{2+}$ in distilled water for 48 $\mathrm{h}$ in the dark. For heat shock similar seedlings were incubated at $37^{\circ} \mathrm{C}$ for $2 \mathrm{~h}$ as described in [39]. Cold shock was given at $4^{\circ} \mathrm{C}$ for $4 \mathrm{~h}$ following the method of [40]. For salt treatment seedlings were treated with $100 \mathrm{mM} \mathrm{NaCl}$ as described in [41] for $24 \mathrm{~h}$ in the dark with aeration. Seedlings were also exposed to $\mathrm{H}_{2} \mathrm{O}_{2}$ at $5 \mu \mathrm{M}, 10 \mu \mathrm{M}, 50 \mu \mathrm{M}$, $100 \mu \mathrm{M}, 500 \mu \mathrm{M}$ and $1 \mathrm{mM} \mathrm{H}_{2} \mathrm{O}_{2}$ for $24 \mathrm{~h}$, changing solutions every $12 \mathrm{~h}$. For metal treatment in mature $B$. juncea four-week-old hydroponically grown plants were transferred to aerated $0.1 \times$ Hoagland's solution containing 50 $\mu \mathrm{M} \mathrm{Ni}^{2+}, 50 \mu \mathrm{M} \mathrm{Zn}^{2+}$ or $5 \mu \mathrm{M} \mathrm{Cd}^{2+}$. To maintain a constant $\mathrm{Cd}^{2+}$ concentration throughout the experiment the hydroponic media was replaced at $12 \mathrm{~h}$ intervals. Because of the higher initial concentration of $\mathrm{Ni}^{2+}$ and $\mathrm{Zn}^{2+}$ their concentrations were found to not significantly change during the experiment, as analyzed by ICP-MS (data not shown). For recovery experiments plants were transferred to aerated $0.1 \times$ Hoagland's solution lacking either $\mathrm{Ni}^{2+}$, $\mathrm{Cd}^{2+}$ or elevated $\mathrm{Zn}^{2+}$. Root and shoot samples were also analyzed for $\mathrm{Ni}^{2+}$ accumulation by ICP-MS. Three independent replicate samples were used for each analysis. For total GUS activity tissue samples were homogenized in liquid nitrogen and suspended in $200 \mu \mathrm{L}$ of extraction buffer (50 mM NaHPO 4 pH 7.0, $2 \mathrm{mM} \mathrm{DTT,} 10 \mathrm{mM} \mathrm{Na}_{2}$ EDTA, $0.1 \%(\mathrm{w} / \mathrm{v})$ sodium lauryl sarcosine and $0.1 \%(\mathrm{v} /$ v) Triton X-100; [42]) and the soluble protein fraction collected after centrifugation at 10,000 × g. Quantitative fluorometric analysis of GUS enzymatic activity was carried out according to [42]. Fluorescence was measured using a luminescence spectrometer (PerkinElmer model \# LS 55, Life and Analytical Sciences Boston, MA) after 60 min incubation with the GUS substrate. Each assay was performed using three independent replicate samples. Total protein content was determined using a BCA protein 
assay kit (Pierce Biotechnology, Rockford, IL). GUS activity data is expressed as nmoles of 4-methylumbelliferone(MU) $\mathrm{min}^{-1} \mathrm{mg}^{-1}$ of extracted protein. Histochemical GUS analysis of $B$. juncea tissues was performed based on a standard protocol [43]. GUS localization was analyzed using an Olympus Vanox light microscope (Olympus America Inc. Melville, NY). For photography a SPOT-RT digital camera (Diagnostic instruments Sterling Heights, MI) attached to the microscope was used. For quantitative fluorometric assay of mRFP1 in tissue samples $100 \mathrm{mg}$ fresh weight of tissue was homogenized in liquid nitrogen and suspended in $200 \mu \mathrm{L}$ of the PBS buffer ( $10 \mathrm{mM}$ potassium phosphate buffer, $140 \mathrm{mM} \mathrm{NaCl}, \mathrm{pH} 7.4)$ containing $1 \mathrm{mM}$ DTT, and the soluble protein fraction collected after centrifugation at $10,000 \times \mathrm{g}$. The relative mRFP1 emission $(607 \mathrm{~nm})$ in the samples was measured using a luminescence spectrometer (model \# LS 55 PerkinElmer Life and Analytical Sciences Boston, MA) after excitation at $584 \mathrm{~nm}$. Each assay was performed using three independent replicate samples. For epifluorescence microscopy tissues were immediately incubated in PBS buffer and hand sections prepared for localization of mRFP1 expression. Epifluorescence was observed using Nikon E 800 compound microscope equipped with Rhodamine Texas red (exciter $\lambda 560 \pm 20$, dichroic $\lambda$ Q $585 \mathrm{LP}$ and emitter $\lambda 610$ LP) filter. For photography SPOT-RT digital camera attached to the microscope was used.

\section{Metal Toxicity Measurements}

Metal toxicity measurements were done using $\mathrm{K}^{+}$leakage in five-day-old seedlings containing $p(1.0) B j M T P 1:: G U S-$ Plus, following a method adapted from [44]. After metal treatment seedlings $(n=5)$ were removed and placed in $10 \mathrm{~mL}$ of distilled water for $60 \mathrm{~min}$, the solution filtered through a $0.2 \mu \mathrm{m}$ filter and $\mathrm{K}^{+}$measured using ICP-MS. Untreated seedlings were used as a control. Seedlings used for $\mathrm{K}^{+}$efflux were dried at $68^{\circ} \mathrm{C}$ for $48 \mathrm{~h}$ and $\mathrm{K}^{+}$leakage expressed on a dry weigh basis.

\section{Inductively Coupled Plasma - Mass Spectroscopy}

Plant tissue sample were washed once in $18 \mathrm{M} \Omega$, dried overnight at $90^{\circ} \mathrm{C}$ weighed and digested in concentrated $\mathrm{HNO}_{3}$ acid (OmniTrace, EM) at $110^{\circ} \mathrm{C}$ for $4 \mathrm{~h}$. Ni, Cd and $\mathrm{Zn}$ were quantified in the samples using an ICP-MS (Elan DRCe, PerkinElmer) following our published methods [45]. K concentration in $\mathrm{K}^{+}$-leakage assays were measured directly in the assay solution using ICP-MS (Elan DRCe, PerkinElmer).

\section{Authors' contributions}

DES conceived the work and guided the experiments; BM was primarily responsible for carrying them out with BY contributing to the cloning. All authors have read and approved the final manuscript

\section{Additional material}

\section{Additional file 1}

Dendrogram of plant MTP1 protein-coding DNA sequencealignments using Neighbor-Joining. A phylogenetic analysis showing the relationships between the plant MTP1 protein-coding DNA sequences.

Click here for file

[http://www.biomedcentral.com/content/supplementary/14712229-7-32-S1.ppt]

\section{Additional file 2}

Tissue localization of MTP1 expression in B. juncea. A microscopic analysis of root cross-sections and lateral roots from 4-week-old $\mathrm{B}$. juncea transformed with $\mathrm{p}$ BjMTP1::mRFP1 or $\mathrm{p}$ BjMTP1::EYFP after exposure to $5 \mu \mathrm{M} \mathrm{Cd} d^{2+}$ or $50 \mu \mathrm{M} \mathrm{Ni}{ }^{2+}$ for $48 \mathrm{~h}$.

Click here for file

[http://www.biomedcentral.com/content/supplementary/14712229-7-32-S2.ppt]

\section{Acknowledgements}

This work was supported by the US Department of Energy (DE-FG02OIER86I35) and the Indiana 2 Ist Century Research and Technology Fund. The authors wish to thank Brett Lahner for ICP-MS analysis and Thomas Leustek of Rutgers University for providing the regeneration/transformation protocol for $B$. juncea. The authors also wish to thank Gerald Myers of SDSU for his help in B. juncea root anatomy, Roger Tsien of UCSD for PRSETB (mRFPI) and Jeff Gustin, Thomas Sors and Elena Yakubova for their helpful advice. We would also like to thank Edenspace Systems Corporation for useful discussions.

\section{References}

I. Kramer U: MTPI mops up excess zinc in Arabidopsis cells. Trends Plant Sci 2005, 10:313-315.

2. Van der Zaal BJ, Neuteboom LW, Pinas JE, Chardonnens AN, Schat H, Verkleij JAC, Hooykaas PJJ: Overexpression of a novel Arabidopsis gene related to putative zinc-transporter genes from animals can lead to enhanced zinc resistance and accumulation. Plant Physiol 1999, I I 9:1047-1056.

3. Kobae $Y$, Uemura T, Sato MH, Ohnishi M, Mimura T, Nakagawa T, Maeshima M: Zinc transporter of Arabidopsis thaliana AtMTP I is localized to vacuolar membranes and implicated in zinc homeostasis. Plant Cell Physiol 2004, 45: I749- 1758.

4. Desbrosses-Fonrouge AG, Voigt K, Schroder A, Arrivault S, Thomine $\mathrm{S}$, Kramer U: Arabidopsis thaliana MTPI is a Zn transporter in the vacuolar membrane which mediates $\mathrm{Zn}$ detoxification and drives leaf $\mathbf{Z n}$ accumulation. FEBS letters 2005, 579:4I65-4I74.

5. Bloß T, Clemens S, Nies DH: Characterization of the ZATIp zinc transporter from Arabidopsis thaliana in microbial model organisms and reconstituted proteoliposomes. Planta 2002, 2 | 4:783-79|

6. Persans MW, Nieman K, Salt DE: Functional activity and role of cation- efflux family members in $\mathrm{Ni}$ hyperaccumulation in Thlaspi goesingense. Proc Natl Acad Sci USA 200I, 98:9995-I0000.

7. Assuncao AGL, Martins PD, De Folter S, Vooijs R, Schat H, Aarts MGM: Elevated expression of metal transporter genes in three accessions of the metal hyperaccumulator Thlaspi caerulescens. Plant Cell Environ 200I, 24:217-226.

8. Drager DB, Desbrosses-Fonrouge AG, Krach C, Chardonnens AN, Meyer RC, Saumitou-Laprade P, Kramer U: Two genes encoding Arabidopsis halleri MTPI metal transport proteins co-segregate with zinc tolerance and account for high MTPI transcript levels. Plant J 2004, 39:425-439.

9. Blaudez D, Kohler A, Martin F, Sanders D, Chalot M: Poplar metal tolerance protein I confers zinc tolerance and is an oligo- 
meric vacuolar zinc transporter with an essential leucine zipper motif. Plant Cell 2003, I 5:29I I-2928.

10. Kim D, Gustin JL, Lahner B, Persans MW, Baek D, Yun DJ, Salt DE: The plant CDF family member TgMTPI from the Ni/Zn hyperaccumulator Thlaspi goesingense acts to enhance efflux of $\mathrm{Zn}$ at the plasma membrane when expressed in Saccharomyces cerevisiae. Plant J 2004, 39:237-25I.

II. Oost EH, Brandenburg WA, Reuling TM, Jarvis CE: Lectotypification of Brassica rapa $L$., B. campestris $L$. and neotypification of B.chinensis L. (Cruciferae). Taxon 1987, 36:625-634.

12. Axelsson T, Bowman CM, Sharpe AG, Lydiate DJ, Lagercrantz U: Amphidiploid Brassica juncea (2000). Genome 2000, 43:679-688.

13. Kumar PBAN, Dushenkov V, Motto V, Raskin I: Phytoextraction: The use of plants to remove heavy metals from soils. Environ Sci Technol 1995, 25: 1232-1238.

14. Salt DE, Smith RD, Raskin I: Phytoremediation. Annu Rev Plant Physiol Plant Mol Biol 1998, 49:643-668.

15. Salt DE, Prince RC, Pickering IJ, Raskin I: Mechanisms of cadmium mobility and accumulation in Indian mustard. Plant Physiol 1995, I09(4): | 427-| 433.

16. Salt DE, Pickering IJ, Prince RC, Gleba D, Dushenkov S, Smith R, Raskin I: Metal accumulation by aquacultured seedlings on Indian mustard. Environ Sci Technol 1997, 3 I:1636-1644.

17. Ebbs SD, Lasat MM, Brady DJ, Cornish J, Gordon R, Kochian LV: Phytoextraction of cadmium and zinc from a contaminated soil. J Environ Qual 1997, 26: |424-| 430.

18. Higo K, Ugawa $Y$, Iwamoto $M$, Korenaga T: Plant cis-acting regulatory DNA elements (PLACE) database: 1999. Nucleic Acids Res 1999, 27:297-300.

19. Lescot M, Dehais P, Thijs G, Marchal K, Moreau Y, Van de Peer Y, Rouze P, Rombauts S: PlantCARE, a database of plant cis-acting regulatory elements and a portal to tools for in silico analysis of promoter sequences. Nucleic Acids Res 2002, 30:325-327.

20. Brugnera E, Georgiev O, Radtke F, Heuchel R, Baker E, Sutherland GR, Schaffner W: Cloning, chromosomal mapping and characterization of the human metal-regulatory transcription factor MTF-I. Nucleic Acids Res 1994, 22:3167-3173.

21. Koizumi S, Suzuki K, Ogra Y, Yamada H, Otsuka F: Transcriptional activity and regulatory protein binding of metal-responsive elements of the human metallothionein-IIA gene. Eur J Biochem 1999, 259:635-642.

22. Larochelle O, Stewart G, Moffat P, Tremblay V, Seguin C: Characterization of the mouse metal-regulatory-element-binding proteins, metal element protein-I and metal regulatory transcription factor-I. Biochem / 200I, 353:59I-60I.

23. Murphy A, Hoogner KR, Peer WA, Taiz L: Identification, purification and molecular cloning of N-I-Naphthylphthalmic acidbinding plasma membrane-associated aminopeptidases from Arabidopsis. Plant Physiol 2002, I 28:935-950.

24. Smith AP, Neurizadeh SD, Peer WA, Xu JH, Bandyopadhyay A, Murphy AS, Goldsbrough PB: Arabidopsis ATGSTF2 is regulated by ethylene and auxin, and encodes a glutathione S-transferase that interacts with flavanoids. Plant / 2003, 36:433-442.

25. Peer WA, Bandyopadhyay A, Blakeslee J], Makam SN, Chen RJ, Masson $\mathrm{PH}$, Murphy AS: Variation in expression and protein localization of the PIN family of auxin efflux facilitator proteins in flavonoid mutants with altered auxin transport in Arabidopsis thaliana. Plant Cell 2004, 16:1898-1911.

26. Terasaka K, Blakeslee IJ, Titapiwatanakun B, Peer WA, Bandyopadhyay A, Makam SN, Lee OR, Richards EL, Murphy AS, Sato F, Yazaki K: PGP4, an ATP binding cassette P-glycoprotein, catalyzes auxin transport in Arabidopsis thaliana roots. Plant Cell 2005, 17:2922-2939.

27. Choi HI, Park HJ, Park JH, Kim S, Im MY, Seo HH, Kim YW, Hwang I, Kim SY: Arabidopsis Calcium-Dependent Protein Kinase AtCPK32 Interacts with ABF4, a Transcriptional Regulator of Abscisic Acid-Responsive Gene Expression, and Modulates Its Activity. Plant Physiol 2005, 139: 1750-176I.

28. Hwang YS, Karrer EE, Thomas BR, Chen L, Rodriguez RL: Three ciselements required for rice alpha-amylase Amy3D expression during sugar starvation. Plant Mol Biol 1998, 36:33I-34I.

29. Boyle $B$, Brisson N: Repression of the defense gene PR-IOa by the single-stranded DNA binding protein SEBF. Plant Cell 200I, 1 3:2525-2537.

30. Chakravarthy S, Tuori RP, Dascenzo MD, Fobert PR, Despres C, Martin GB: The tomato transcription factor Pti4 regulates defense-related gene expression via GCC box and non-GCC box cis elements. Plant Cell 2003, 15:3033-3050.

3I. Hoagland DR, Arnon DI: The water-culture method for growing plants without soil. Calif Agric Exp Sta Circ 1950, 347:I-32.

32. Rider SD, Henderson JT, Jerome RE, Edenberg HJ, Romero-Severson J. Ogas J: Coordinate repression of regulators of embryonic identity by PICKLE during germination in Arabidopsis. Plant J 2003, 35:33-43.

33. Livak JL, Schmittgen TD: Analysis of relative gene expression data using real-time quantitative PCR and the $2^{-\Delta \Delta} \mathbf{C t}$ method. Methods 200I, 25:402-408.

34. Altschul SF, Madden TL, Schaffer AA, Zhang J, Zhang Z, Miller W, Lipman DJ: Gapped BLAST and PSI-BLAST: a new generation of protein database search program. Nucleic Acids Res 1997, 25:3389-3402.

35. Reese MG: Application of a time-delay neural network to promoter annotation in the Drosophila melanogaster genome. Comput Chem 200I, 26:5I-56.

36. Hellens RP, Edwards EA, Leyland NR, Bean S, Mullineaux PM: pGreen: A versatile and flexible binary Ti vector for Agrobacterium-mediated plant transformation. Plant Mol Biol 2000, 42:819-832

37. Campbell RE, Tour O, Palmer AE, Steinbach PA, Baird GS, Zacharias DA, Tsien RY: A monomeric red fluorescent protein. Proc Natl Acad Sci USA 2000, 99:7877-7882.

38. Murashige T, Skoog F: A revised medium for rapid growth and bio assays with tobacco tissue cultures. Physiol Plant 1962, I 5:473-497.

39. Matsuhara S, Jingu F, Takahashi T, Komeda Y: Heat- shock tagging: a simple method for expression of plant genome DNA flanked by T-DNA insertions. Plant J 2000, 22:79-86.

40. Fowler S, Thomashow MF: Arabidopsis transcriptome profiling indicates that multiple regulatory pathways are activated during cold acclimation in addition to the CBF cold response pathway. Plant Cell 2002, 14:1675-1690.

4I. Shi H, Quintero FJ, Pardo JM, Zhu JK: The putative plasma membrane $\mathrm{Na}^{+} / \mathrm{H}^{+}$antiporter SOSI controls long-distance $\mathrm{Na}^{+}$ transport in plants. Plant cell 2002, I4:465-477.

42. Gallagher SR: Quantitation of GUS activity by fluorometry. In GUS Protocols Edited by: Gallagher SR. San Diego: Academic Press; 1992:47-60

43. Rodrigues-Pousada RA, Rycke RD, Dedonder AW, Caeneghem VG, Almeida-Engler J, Van Montagu M, Straeten DVD: The Arabidopsis I- Aminocyclopropane-I-Carboxylate Synthase Genel is Expressed during Early Development. Plant Cell 1993, 5:897-9II.

44. Murphy AS, Eisinger WR, Shaff JE, Kochian LV, Taiz L: Early CopperInduced Leakage of $\mathrm{K}^{+}$from Arabidopsis Seedlings Is Mediated by Ion Channels and Coupled to Citrate Efflux. Plant Physiol 1999, I 2 I: | 375- I 382

45. Lahner B, Gong J, Mahmoudian M, Smith EL, Abid KB, Rogers EE, Guerinot ML, Harper JF, Ward JM, et al.: Genomic scale profiling of nutrient and trace elements in Arabidopsis thaliana. Nat Biotechnol 2003, 21:1215-1221.

Publish with Bio Med Central and every scientist can read your work free of charge

"BioMed Central will be the most significant development for disseminating the results of biomedical research in our lifetime. "

Sir Paul Nurse, Cancer Research UK

Your research papers will be:

- available free of charge to the entire biomedical community

- peer reviewed and published immediately upon acceptance

- cited in PubMed and archived on PubMed Central

- yours - you keep the copyright

Submit your manuscript here:

http://www.biomedcentral.com/info/publishing_adv.asp
BioMedcentral 